\title{
Effect of Pouring Temperature on Mechanical Properties of Semisolid Cast A319 Aluminum Alloy
}

\author{
Manas Ranjan Padhi, Chitta Ranjan Routray
}

\begin{abstract}
Semisolid metal (SSM) casting or thixoforming is a technique used to produce near net-shaped products. The process is used with non-ferrous metals, such as aluminium, copper and magnesium. Furthermore, it has advantage over conventional casting due to suppression of dendrite growth. In the present work, the semisolid casting of A319 aluminium alloy has been carried out by using an inclined plate with different melt pouring temperatures (620, 625, 630 and $\left.635{ }^{\circ} \mathrm{C}\right)$. A319 alloy melt undergoes partial solidification when it flows down on an inclined plate. It results in continuous formation of columnar dendrites on plate wall. Due to forced convection, these dendrites are sheared off into equiaxed or fragmented grains and then washed away continuously to produce semisolid slurry at plate exit. The prepared castings were checked for their mechanical properties like tensile, hardness and impact strength. The results obtained were compared with that of alloy prepared from conventional sand casting. It was found that there is an enhancement in mechanical properties due to shearing off columnar dendrites.
\end{abstract}

Keywords: casting, mechanical properties, pouring temperature, semisolid

\section{INTRODUCTION}

Aluminium and its alloys are widely used in industries particularly automobile, aerospace and defense due to their light weight. Aluminium has a density one third the density of steel. It is easy to produce aluminium due to its good thermal and electrical conductivity and it does not exhibit a transition from ductile to brittle phase at low temperatures. The aluminium castings are extensively used in automobile industries for making piston, cylinder liners, wheels, brackets, brake parts, control arm, cylinder heads and instrument panels [1]. The solidification process of the liquid metal plays a crucial role in determining the physical and mechanical properties of the alloy. The conventional casting may have casting defects and low strength due to dendritic microstructure of the alloys. Several techniques have been

Revised Manuscript Received on February 05, 2020.

* Correspondence Author

Manas Ranjan Padhi*, Mechanical Engineering, Centurion University of Technology \& Management, Bhubaneswar, India. E-mail: manas.padhi@cutm.ac.in

Chitta Ranjan Routray, Mechanical Engineering, Centurion University of Technology \& Management, Bhubaneswar, India. E-mail: crroutray2017@gmail.com

(C) The Authors. Published by Blue Eyes Intelligence Engineering and Sciences Publication (BEIESP). This is an open access article under the CC BY-NC-ND license (http://creativecommons.org/licenses/by-nc-nd/4.0/) developed to produce alloy of non-dendritic microstructure, out of which stir casting is noteworthy [2]. The effect of steering on solidification pattern and alloy distribution during semisolid metal casting has also been studied [3]. Flemings [4] investigated the effect of convection that occurs due to mechanical or electromagnetic stirring technique during solidification of liquid metal. Cooling slope casting is alternative technique used in semisolid metal processing which is simple and cost effective [5]. In this process, molten metal is poured on the top of an inclined cooling plate. Due to forced convection, the columnar dendrites formed during solidification are broken into refined and globular microstructure [6]. The semisolid slurry is then solidified in mould cavity. This technology promises some advantages such as prolonged die life due to less thermal shock and also provides more laminar cavity fill which could lead to reduced gas entrapment. The components formed in semisolid metal casting process have superior mechanical and properties because of globular or thixotropic microstructure [7-9]. Application of vibration is another method in semisolid metal (SSM) processing to produce thixotropic microstructure of cast components. It has also been reported that applying mechanical and ultrasonic vibration in the semisolid metal processing can lead to formation of fine, non-dendritic and globular microstructure. However these techniques are time consuming and not cost effective [10]. Therefore a process using minimal equipment is required to reduce the cost of the semisolid metal processing (SSM) [11]. This process is mainly used to cast complex products with near net shapes and excellent dimensional accuracy. Several works of semisolid metal processing on aluminium alloy A356, A357, A390, A319 have been carried out using cooling slope technique [12]. The effect of cooling slope parameters such as plate length, plate inclination, pouring temperature of liquid metal and flow rate of water on microstructure of alloy is critically studied [13]. However substantial investigation on mechanical properties of semisolid cast alloy has not been reported. In the present work, billets of aluminium alloy A319 were prepared using cooling slope technique and effect of pouring temperature on mechanical properties is analyzed by comparing with the conventional cast sample. 


\section{MATERIALS AND METHOD}

\section{A. Material Composition}

The aluminium alloy A319 with solidus temperature of $507^{\circ} \mathrm{C}$ and liquidus temperature of $611^{\circ} \mathrm{C}$ was used as the material for experiment. It was tested by using $\mathrm{X}$-ray fluorescence (XRF) to determine its composition. For this purpose, $5 \mathrm{~mm}$ thickness of material was cut from alloy. It was polished and

tested in XRF machine. The composition of A390 aluminium alloy was reported in Table- I.

Table- I: Composition of A319 aluminium alloy

\begin{tabular}{|l|l|l|l|l|l|l|}
\hline $\mathrm{Al}$ & $\mathrm{Si}$ & $\mathrm{Cu}$ & $\mathrm{Fe}$ & $\mathrm{Cl}$ & $\mathrm{Zn}$ & $\mathrm{Mn}$ \\
\hline 86.377 & 7.649 & 2.055 & 1.312 & 0.281 & 1.644 & 0.160 \\
\hline
\end{tabular}

\section{B. Experimental Setup}

The experimental setup consists of melting furnace, an inclined plate and sand mould as shown in Fig. 1. About 1500 gm of aluminium alloy was melted in a melting furnace. The molten alloy was slowly poured over an mild steel inclined plate of $450 \mathrm{~mm}$ in length held at an angle of $60^{\circ}$. The pouring temperature was around $625^{\circ} \mathrm{C}$. The top of the inclined plate was provided with K-type thermocouple to monitor the pouring temperature of the molten aluminum alloy. The semisolid slurry obtained at the lower end of the inclined plate was solidified in a sand mould. A round billet of aluminium alloy of size $250 \mathrm{~mm}$ length and $25 \mathrm{~mm}$ diameter was obtained in this casting process by using an inclined plate as shown in Fig. 2. Similarly four numbers of aluminium alloy round billets were prepared at different pouring temperatures. Several tests have been conducted to investigate the effect of pouring temperature on mechanical properties of A319 Aluminium alloy. To compare the mechanical properties, another sample of A319 is prepared through conventional sand casting process.

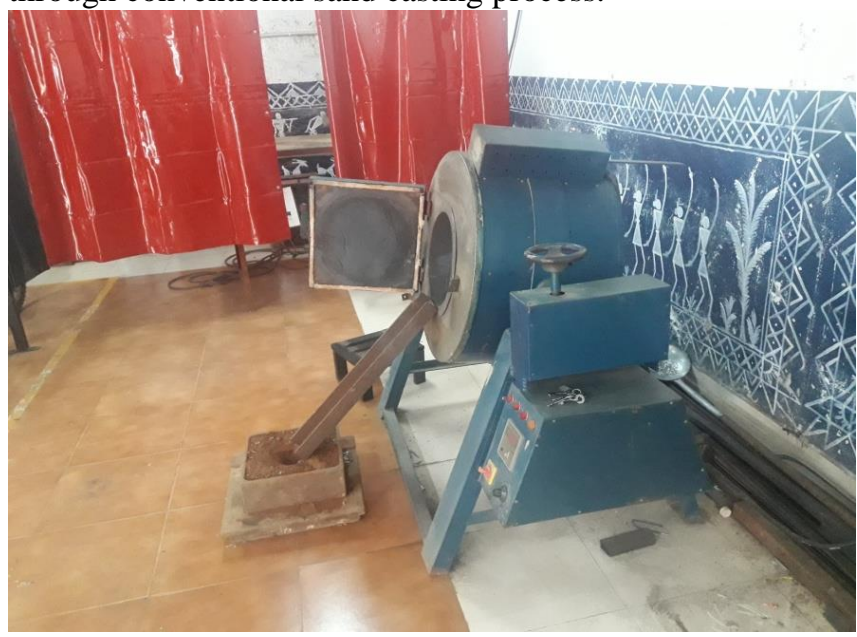

Fig. 1.Experimental setup

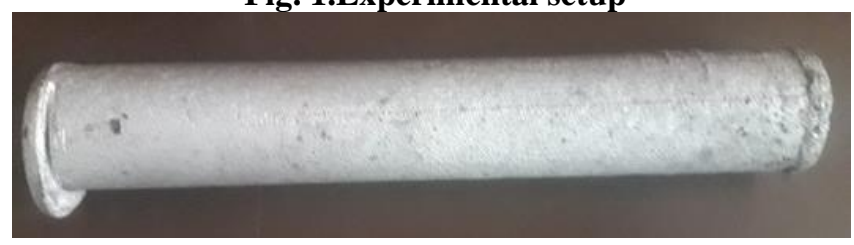

Fig. 2.Semisolid cast A319 alloy billet

\section{Tensile Test}

In order to investigate the mechanical properties of A319 alloy cast billets, tensile test was conducted in Universal
Testing Machine (UTM) as shown in Fig. 3. The tensile test specimen of size $210 \mathrm{~mm}$ length and $25 \mathrm{~mm}$ diameter was cut from semi solid cast bar. It was brought to the ASTM standard (E8) of gauge length $50 \mathrm{~mm}$ and diameter $12.5 \mathrm{~mm}$ by machining properly. The specimen was fixed up in between upper cross head and lower cross head with the help of jaws on the loading side. The load valve was gradually opened to apply gradual tensile load on the sample till it breaks. The ultimate tensile strength of specimen was measured and noted down after fracture. Similarly, the tensile test was carried out for all four samples of semisolid cast A319 alloy prepared at different pouring temperatures and was compared with the value obtained from testing of convention cast sample.

\section{Hardness Test}

The hardness tests of the A319 alloy samples were conducted by using Rockwell hardness testing machine as shown in Fig. 4. To conduct the test, specimen of diameter $25 \mathrm{~mm}$ and thickness $5 \mathrm{~mm}$ were cut from conventional and semisolid cast billets respectively. The specimens were properly machined and polished before mounting in the hardness testing machine. The ball indenter of diameter $1.5875 \mathrm{~mm}$ was used on hardness testing machine. The hardness measurements were taken after imposing a load of $588.4 \mathrm{~N}$ in F scale.

\section{E. Impact Test}

The charpy impact test was conducted to determine the impact strength of the semisolid cast A319 alloy. The test is to determine the behavior of materials when subjected to high rates of (sudden) loading, usually bending, tension or torsion. It measures the energy absorbed in breaking the specimen by a single blow or impact. Charpy test was conducted for both as-cast and semisolid samples of A319 alloy. For this purpose, full size Charpy V-notch $10 \times 10 \times 55 \mathrm{~mm}$ impact specimens according to ASTM E23 were used. The pendulum of drop angle $148^{\circ}$ and weight of $20.996 \mathrm{~kg}$ was used to give impact on the test pieces.

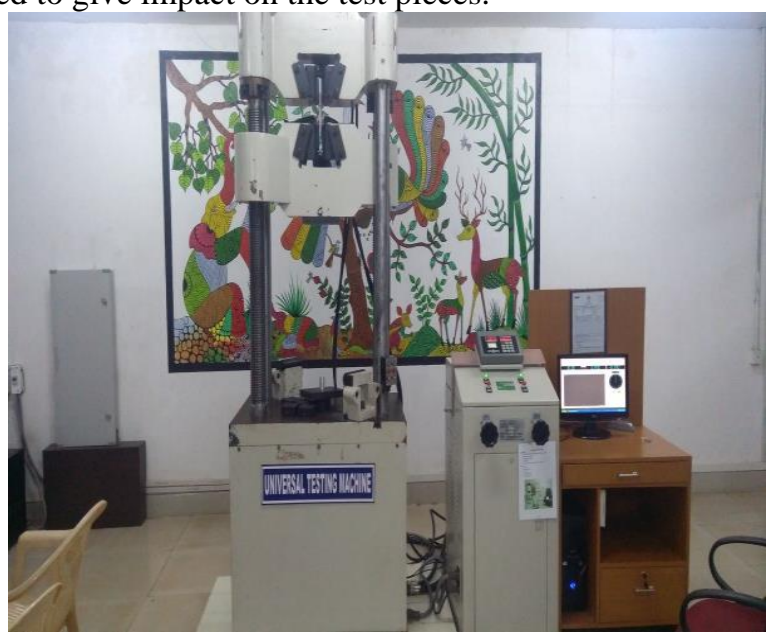

Fig. 3.Tensile test on Universal Testing Machine 


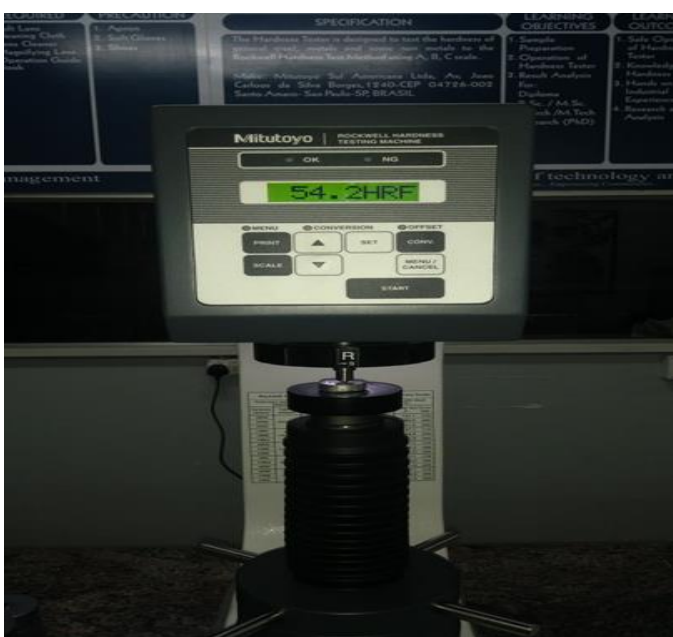

Fig. 4.Hardness test on Rockwell hardness testing machine

\section{RESULTS AND DISCUSSION}

The results obtained from tensile tests of samples of A319 alloy are shown in Table-II. From the values of ultimate tensile strength and yield strength, it is apparent that there is an increase in tensile strength of semisolid cast test piece in comparison to conventional cast as shown in Fig. 5. This may be due to breaking of dendrites as a result of shearing effect when the slurry flows down the inclined plate. Furthermore, it is observed that the values of ultimate tensile strength and yield strength of semisolid cast samples decreases with increasing pouring temperature. This is due to the reason that low pouring temperature causes rapid solidification of melt on the slope for semisolid casting.

Table- II: Results of Tensile Test

\begin{tabular}{|l|l|l|l|}
\hline Sample & $\begin{array}{l}\text { Pouring } \\
\text { temperature of } \\
\text { molten alloy }\end{array}$ & $\begin{array}{l}\text { Ultimate } \\
\text { Tensile } \\
\text { Strength } \\
\text { (MPa) }\end{array}$ & $\begin{array}{l}\text { Yield } \\
\text { Strength } \\
\text { (MPa) }\end{array}$ \\
\hline $\begin{array}{l}\text { Sample-1 } \\
\text { (Conventional cast) }\end{array}$ & 620 & 208 & 110 \\
\hline $\begin{array}{l}\text { Sample-2 } \\
\text { (Semisolid Cast) }\end{array}$ & 620 & 236 & 136 \\
\hline $\begin{array}{l}\text { Sample-3 } \\
\text { (Semisolid Cast) }\end{array}$ & 625 & 234 & 133 \\
\hline $\begin{array}{l}\text { Sample-4 } \\
\text { (Semisolid Cast) }\end{array}$ & 630 & 228 & 128 \\
\hline $\begin{array}{l}\text { Sample-5 } \\
\text { (Semisolid Cast) }\end{array}$ & 635 & 225 & 124 \\
\hline
\end{tabular}

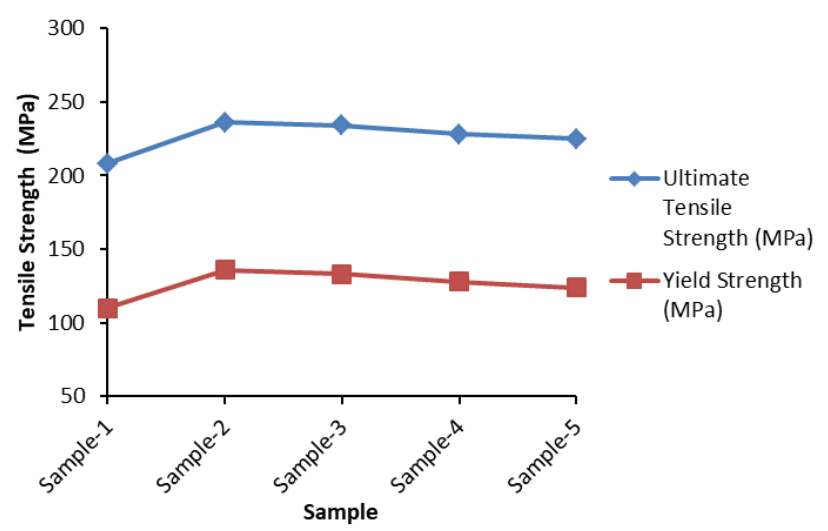

Fig. 5.Tensile strength of A319 alloy samples

The results obtained from the hardness test and impact test are presented in Table-III and IV. The hardness numbers and impact energy corresponding to conventional cast and semisolid cast samples prepared at different pouring temperatures are shown in Fig. 6 and 7. It can be observed that the hardness number of the semisolid cast test samples increases by 20 percent from that of conventional cast test samples whereas the impact strength increases by 16 percent. There is a decreasing trend in values of hardness and impact energy of semisolid cast samples corresponding to different pouring temperatures. Higher pouring temperature results a delay in solidification of melt when it flows down the inclined plate. Therefore, the slurry temperature at plate exit increases with increasing the melt pouring temperature that results in lower solid fraction at higher melt pouring temperature and hence, decrease in hardness and impact energy.

Table- III: Results of Hardness Test

\begin{tabular}{|lr|l|l|}
\hline \multicolumn{2}{|l|}{ Sample } & $\begin{array}{l}\text { Pouring temperature } \\
\text { of molten alloy }\end{array}$ & $\begin{array}{l}\text { Hardness Number } \\
\text { (HRF) }\end{array}$ \\
\hline $\begin{array}{l}\text { Sample-1 } \\
\text { cast) }\end{array}$ & (Conventional & 620 & 54.2 \\
\hline $\begin{array}{l}\text { Sample-2 } \\
\text { Cast) }\end{array}$ & (Semisolid & 620 & 68 \\
\hline $\begin{array}{l}\text { Sample-3 } \\
\text { Cast) }\end{array}$ & (Semisolid & 625 & 67.2 \\
\hline $\begin{array}{l}\text { Sample-4 } \\
\text { Cast) }\end{array}$ & (Semisolid & 630 & 66.5 \\
\hline $\begin{array}{l}\text { Sample-5 } \\
\text { Cast) }\end{array}$ & (Semisolid & 635 & 65.8 \\
\hline
\end{tabular}

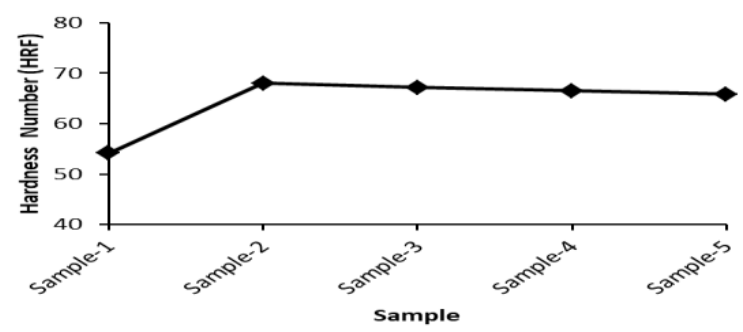

Fig.6. Hardness numbers of A319 alloy samples

Table- IV: Results of impact test

\begin{tabular}{|l|l|l|}
\hline Sample & $\begin{array}{l}\text { Pouring } \\
\text { temperature } \\
\text { molten alloy }\end{array}$ & $\begin{array}{l}\text { Impact } \\
\text { Energy (N-m ) }\end{array}$ \\
\hline $\begin{array}{l}\text { Sample-1 (Conventional } \\
\text { cast) }\end{array}$ & 620 & 6.8 \\
\hline Sample-2 (Semisolid Cast) & 620 & 8.5 \\
\hline Sample-3 (Semisolid Cast) & 625 & 8.2 \\
\hline Sample-4 (Semisolid Cast) & 630 & 7.6 \\
\hline Sample-4 (Semisolid Cast) & 635 & 7.2 \\
\hline
\end{tabular}

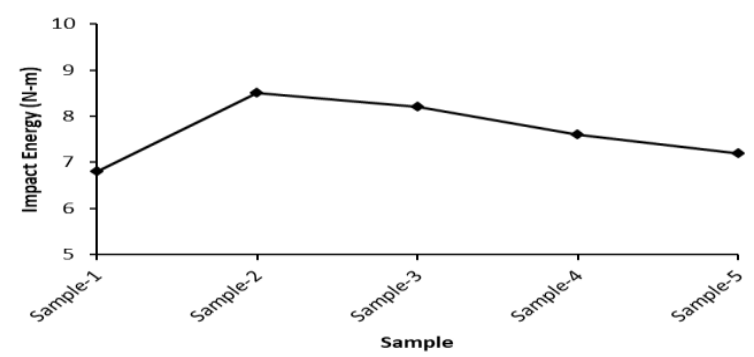

Fig.7. Impact energy of A319 alloy samples

Published By:

Blue Eyes Intelligence Engineering 


\section{CONCLUSION}

Semisolid metal casting of aluminium alloy A319 was prepared with an inclined plate of length $450 \mathrm{~mm}$ held at angle of $60^{\circ}$. Several tests were conducted to determine the mechanical properties of the samples of semisolid cast alloy. The values of mechanical properties such as tensile strength, hardness and impact energy for semisolid cast alloy were compared with that made from conventional casting and were found to have increased due to breaking of columnar dendrites. Furthermore, experimental investigation was carried out with different melt pouring temperatures over the inclined plate. The mechanical properties such as ultimate tensile strength, yield strength, hardness number, impact strength are optimum at the melt pouring temperature of $620^{\circ} \mathrm{C}$ for semisolid cast alloy samples. There is a decline in mechanical properties with the increase in melt pouring temperature as higher pouring temperature results a delay in solidification of melt when it flows down the inclined plate.

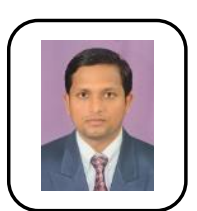

Chitta Ranjan Routray is pursuing his M.Tech in Mechanical Engineering, Centurion University of Technology and Management, Odisha. His specialisation is Design and Manufacturing. He has completed his B.Tech. from krupajal Engineering College, BPUT, Odisha.

\section{REFERENCES}

1. Du Jun, Liu Yao-hui, Yu Si-rong, Li Wen-fang, "Dry sliding friction and wear properties of $\mathrm{Al}_{2} \mathrm{O}_{3}$ and carbon short fibres reinforced $\mathrm{Al}-12 \mathrm{Si}$ alloy hybrid composites", Wear, vol. 257, 2004, pp. 930-940.

2. T. Haga, "Casting of aluminium alloy Ingot for thixoforming using a cooling slope", Journal of material processing technology, 2001, pp. 169-172.

3. S. Nafisi and R. Ghomashchi, "Effect of string on solidification pattern and alloy distribution during semi-solid metal casting", Materials Science and Engineering A, vol. 437, 2006, pp. 388-395.

4. M. C. Flemings, "Behavior of metal alloys in the semisolid state", Metallurgical Transactions A, vol. 22, 1991, pp. 957-981.

5. S. Saffari and F. Akhlaghi, "Microstructure and mechanical properties of Al-Mg2Si composite fabricated in-situ by vibrating cooling slope", Trans. Nonferrous Met. Soc. China, vol. 28, 2018, pp. 604-612.

6. N. K. Kund \& P. Dutta, "Numerical simulation of solidification of liquid aluminum alloy flowing on cooling slope", Trans. Nonferrous Met. Soc. China, vol. 20, 2010, pp. 898-905.

7. D. H. Kirkwood, "Semi-solid metal processing", Int Mater Rev, vol. 39, 1994, pp. 173-189.

8. Z. Fan, "Semisolid metal processing", Int Mater Rev, vol. 47, 2002, pp. 49-85.

9. M. S. Salleh, M. Z. Omar, J. Syarif, K. S. Alhawari, M. N. Mohammeda, "Microstructure and mechanical properties of thixoformed A319 aluminium alloy", Materials and Design, vol. 64, 2014, pp. 142-152.

10. S. Janudom1, T. Rattanochaikul1, R. burapa, S. Wisutmethangoon, J. Wannasin, "Feasibility of semi-solid die casting of ADC12 aluminum alloy", Trans. Nonferrous Met. Soc. China, vol. 20, 2010, pp. 1756-1762.

11. Yucel Birol, "Cooling slope casting and thixoforming of hypereutectic A390 alloy", vol. 207, 2008, pp. 200-203.

12. I. S. Mahallawia, T.S. Mahmoudb, A. M. Gaaferb, F. H. Mahmoudb, "Effect of Pouring Temperature and Water Cooling on the Thixotropic Semi-solid Microstructure of A319 Aluminium Cast Alloy”, vol. 18, 2015, pp. 170-176

13. Z. K. Zhengi, Y. J. JI, W. M. Mao, R. Yue, Z. Y. Liu, "Influence of rheo-diecasting processing parameters on microstructure and mechanical properties of hypereutectic $\mathrm{Al}-30 \% \mathrm{Si}$ alloy", Trans. Nonferrous Met. Soc. China, vol. 27, 2017, pp. 1264-1272.

\section{AUTHORS PROFILE}

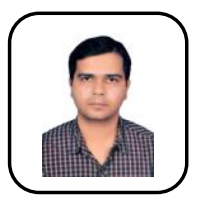

Manas Ranjan Padhi is working as an Assistant Professor in Mechanical Engineering Department, Centurion University of Technology and Management, Odisha. He recived his M.Tech degree from C.V. Raman College of Engineering, BPUT, Odisha. His research interest is semisolid metal processing. He has published a number of papers in the area of metal casting. 